\title{
Tugas Dan Fungsi Kejakasaan Dibidang Pengamanan Proyek Strategis Nasional Sebagai Upaya Pencegahan Tindak Pidana Korupsi
}

\section{KETUT KASNA DEDI}

\section{Iketutkasnadedi@gmail.com}

Program Studi Magister Hukum

Fakultas Hukum Universitas Airlangga Surabaya

\begin{abstract}
Abstrak
"Upaya Kejaksaan RI dalam mencegah dan menanganni tindak pidana korupsi dalam proyek strategis nasional serta mengkaji batasan wewenang dan tugas kejaksaan dalam pencegahan dan penanggulangan tindak pidana korupsi dan sebagai penegak hukum. Menarik untuk dicermati bahwa selama ini masyarakat hanya melihat kejaksaan sebagai lembaga yang berwenang melakukan penyidikan dan penuntutan tindak pidana, tetapi ternyata kejaksaan juga memiliki fungsi melakukan upaya pencegahan tindak pidana seperti melakukan penerangan dan penyuluhan hukum ke masyarakat."
\end{abstract}

Kata Kunci : Kejakasaan, Pengamanan Proyek Strategis Nasional, Upaya Pencegahan Tindak Pidana Korupsi.

\section{PENDAHLUAN}

Kejaksaan sebagai salah satu

lembaga yang berwenang dan bertugas

untuk melakukan penerangan hukum dan

penyuluhan hukum ke masyarakat

sebagaimana yang tercantum di dalam

Undang-Undang Nomor 16 Tahun 2004

tentang Kejaksaan Agung Republik

Indonesia dalam Pasal 30 ayat (3) huruf a

yang menyatakan "Dalam Bidang

Ketertiban dan Ketentraman Umum,

Kejaksaan terus menyelenggarakan

kegiatan peningkatan kesadaran hukum masyarakat". hal tersebut dapat menjadi

instrument Kejaksaan guna meningkatkan

kesadaran masyarakat terhadap hukum

terutama dalam hal pencegahan dan

penanggulangan tindak pidana korupsi.

Dalam upaya pelaksanaan proyek

strategis nasional, kejaksaan mempunyai

peran penting dalam upaya pencegahan

tindak pidana korupsi dengan memberikan

pendampingan hukum terhadap

penyelenggara pemerintah guna mencegah

terjadinya tindak pidana korupsi. 
Dalam usaha memperkuat prinsip-

prinsip negara hukum, diperlukan norma-

norma hukum maupun peraturan

perundang-undangan, juga aparatur

pengemban dan penegak hukum yang

professional, berintegritas dan disiplin yang

di dukung oleh sarana dan prasarana hukum

serta perilaku hukum masyarakat. Oleh

karena itu, idealnya setiap negara hukum

termasuk negara Indonesia harus memiliki

lembaga/institusi/aparat penegak hukum

yang berkualifikasi demikian. ${ }^{1}$

Pelaksanaan otonomi daerah

merupakan suatu wujud demokrasi yang

diberikan Pemerintah Pusat kepada

Pemerintah daerah untuk mengurus sendiri rumah tanggannya dengan tetap berpegang kepada peraturan perundangan yang berlaku. Pemerintah daerah bebas berkreasi dan berekspresi dalam rangka membangun daerahnya, tentu saja dengan tidak melanggar ketentuan perundang-undangan.

\footnotetext{
${ }^{1}$ Marwan Effendy, Kejaksaan RI Posisi dan Fungsinya dari Perspektif Hukum, Jakarta; Gramedia, Pustaka Umum, Jakarta, 2004, h. 2
}

Otonomi daerah dirancang dengan tujuan agar daerah-daerah dapat memanagement secara mandiri segala sumberdaya, keuangan, maupun sumber-sumber lain sebagai pendapatan bagi daerah. Antusias yang tinggi "untuk meningkatkan kemajuan daerah" terlihat dari banyaknya daerahdaerah yang meminta dimekarkan sehingga terjadi pemekaran daerah besar-besaran di seluruh wilayah Indonesia. Yang menarik dari "proses mekarnya suatu daerah" ini adalah menjamurnya praktik korupsi yang dilakukan oleh oknum yang bernama pemimpin/petinggi di daerah.

Pemerintahan sebagai suatu kenyataan yang tak dapat dihindarkan dalam hidup setiap warga negara memiliki banyak arti bagi mereka, secara perorangan atau bersama-sama. R.Wallace Brewster ${ }^{2}$ menyatakan bahwa pemerintah adalah suatu badan melalui mana negara bertindak, dan karenanya diberi kekuasaan penegakan

\footnotetext{
2 Achmad Ali,Menguak Teori Hukum (Legal Theory) dan Teori Peradilan (Judicialprudence) Termasuk Interpretasi UndangUndang (Legisprudence), Kencana, Jakarta, 2009, h. 376
} 
hukum yang terakhir, dan yang kemudian juga menjadikan pemerintah sebagai tempat pembuatan keputusan akhir dari masalah-masalah sosial. Atau dalam ungkapan yang lebih sederhana, pemerintah adalah harapan dan peluang untuk mewujudkan hidup yang sejahtera dan berdaulat melalui pengelolaan kebebasan dan persamaan yang dimiliki oleh warga negara. Pada sisi lain, pemerintah adalah pula tantangan dan kendala bagi warga negara terutama ketika pemerintah terjauhkan dari pengamalan etika pemerintahan. Kedua kemungkinan ini adalah suatu kondisi yang berpotensi menjadi kenyataan dalam kehidupan berbangsa dan bernegara. Persoalan yang perlu diselesaikan adalah bagaimana memilih model pemerintahan yang sesuai dengan nilai-nilai kebangsaan dan mengimplementasikan model tersebut secara konsisten. Tidak ada model yang sempurna, dan karenanya yang diperlukan adalah pengembangan dan perbaikan. Melalui cara ini, suatu sistem pemerintahan dapat diharapkan semakin dapat memenuhi aspirasi warga negaranya, dan membawa mereka pada tujuan kehidupan yang lebih baik dari waktu ke waktu, sesuai dengan makna kehidupan dan nilai kebahagiaan yang mereka rumuskan dan amalkan. Sejalan dengan tujuan mewujudkan masyarakat yang sejahtera dan berdaulat, pemerintah suatu negara secara terusmenerus akan melakukan kegiatankegiatan perubahan ke arah yang lebih baik. Bagi negara-negara yang sedang berkembang, rangkaian kegiatan itu merupakan tugas .

Indonesia dalam posisinya sebagai salah satu negara berkembang di dunia, berusaha membuat pembenahan di segala bidang dan berbagai aspek untuk mengangkat ketertinggalannya. Dengan perbaikan melalui pembangunan dalam proses pengembangan negara melalui pembangunan terjadi permasalahan salah satunya adalah korupsi yang terjadi 
dalam proses pembangungan yang dilakukan oleh oknum-oknum tertentu. ${ }^{3}$

Korupsi yang terjadi di Indonesia saat ini sudah dalam posisi yang sangat parah dan begitu mengakar dalam setiap sendi kehidupan. Perkembangan praktik korupsi dari tahun ke tahun semakin meningkat, baik dari kuantitas atau jumlah kerugian Negara maupun dari segi kualitas semakin sistematis, canggih serta ruang lingkupnya sudah meluas dalam seluruh aspek masyarakat. ${ }^{4}$

Penelitian ini dimaksudkan untuk mengkaji upaya Kejaksaan RI dalam mencegah dan menanganni tindak pidana korupsi dalam proyek strategis nasional serta mengkaji batasan wewenang dan tugas kejaksaan dalam pencegahan dan penanggulangan tindak pidana korupsi dan sebagai penegak hukum. Menarik untuk dicermati bahwa selama ini masyarakat hanya melihat kejaksaan sebagai lembaga

${ }^{3}$ Chaerul Amir, Kejaksaan Memberantas Korupsi (Suatu Analisis : Historis, Sosiologis, dan Yuridis), PRO dealeader, Jakarta, 2014,h. 6

${ }^{4}$ Ibid., yang berwenang melakukan penyidikan dan penuntutan tindak pidana, tetapi ternyata kejaksaan juga memiliki fungsi melakukan upaya pencegahan tindak pidana seperti melakukan penerangan dan penyuluhan hukum ke masyarakat.

Berdasarkan uraian latar belakang masalah di atas, maka masalah yang akan dibahas dalam penelitian ini, yaitu: Bagaimana Fungsi Kejaksaan dalam Pengamanan Pembangunan Strategis?

\section{METODE PENELITIAN}

"Melalui penelitian yuridis normatif dengan pertimbangan bahwa titik tolak penelitian analisis terhadap peraturan perundang-undangan pada kerangka hukum nasional Indonesia sendiri. Maka tipe penelitian yang digunakan adalah penelitian juridis normatif, yakni penelitian yang difokuskan untuk mengkaji penerapan kaidah kaidah atau norma-norma pada hukum positif, ${ }^{5}$

5 Peter Mahmud Marzuki, Penelitian Hukum, Kencana Prenada Media Group,Jakarta, 2005, h.171. 
"Pada penelitian ini menggunakan Pendekatan perundang-undangan (statute approach), Pendekatan konseptual (conceptual approach). Pendekatan perundang-undangan (statute approach) Pendekatan perundang-undangan (statute approach) dan Pendekatan konseptual (conceptual approach). Pendekatan perundangan-undangan (statute approach) diperlukan guna mengkaji lebih lanjut mengenai dasar hukum. Pendekatan undang-undang dilakukan dengan menelaah semua undangundang dan regulasi yang bersangkut paut dengan isu hukum yang sedang ditangani ${ }^{6}$.

Dalam penelitian ini juga menggunakan pendekatan konseptual (conceptual approach) ${ }^{7}$ pendekatan yang beranjak dari pandanganpandangan dan doktrin-doktrin yang berkembang didalam ilmu hukum.
Dengan menelaah pandanganpandangan dan doktrin-doktrin tersebut dengan penafsiran sistematisasi terhadap bahan-bahan hukum tertulis agar diperoleh hasil analisa hukum, yang dimaksud pendekatan konsep di sini adalah pendekatan dengan memahami konsep-konsep yang diajukan dalam permasalahan pendekatan yang penulis lakukan adalah pendekatan terhadap Undangundang terkait.

\section{PEMBAHASAN}

\section{A. Fungsi Kejaksaan dalam}

\section{Pengamanan Pembangunan}

\section{Strategis}

Sehubungan dengan fungsi tugaas kejaksaan sebagai lembaga pengekanan hukm, Kejaksaan juga menjalankan fungsi preventif terhadap tindak pidana korupsi. Berdasarkan Peraturan Presiden Republik Indonesia Nomor 38 Tahun 2010 dan

\footnotetext{
${ }^{7}$ Ibid,
} 
Peraturan Jaksa Agung Republik Indonesia

Nomor : PER-009/A/JA/01/2011 tanggal

24 Januari 2011 tentang Organisasi dan

Tata Kerja Kejaksaan Republik Indonesia,

khususnya Pasal 622 disebutkan tugas

pokok dan fungsi intelijen Kejaksaan

berdasarkan adalah unsur pembantu

pimpinan mempunyai tugas dan wewenang

sebagai berikut:

1. Melakukan kegiatan intelijen penyelidikan, pengamanan dan penggalangan untuk melakukan pencegahan tindak pidana guna mendukung penegakan hukum baik preventif maupun represif di bidang ideologi, politik, ekonomi, keuangan, sosial budaya, pertahanan dan keamanan, melaksanakan cegah tangkal terhadap orang-orang tertentu dan/atau turut menyelenggarakan ketertiban dan ketentraman umum dan penanggulangan tindak pidana serta perdata dan tata usaha negara di daerah hukumnya;

2. Memberikan dukungan intelijen Kejaksaan bagi keberhasilan tugas dan kewenangan Kejaksaan, melakukan kerjasama dan koordinasi serta pemantapan kesadaran hukum masyarakat di daerah hukumnya. Kemudian lebih lanjut berdasarkan Pasal 623, dalam melaksanakan tugas sebagaimana dimaksud dalam Pasal 622 ayat (1) dan ayat (2) Seksi Intelijen menyelenggarakan fungsi :

a. Perumusan kebijakan teknis kegiatan dan operasi intelijen Kejaksaan berupa pemberian bimbingan dan pembinaan dalam bidang tugasnya; b. Melakukan koordinasi, perencanaan dan penyusunan kebijakan pada Seksi Intelijen dengan didasarkan sinkronisasi pelaksanaan kebijakan dengan Seksi terkait;

c. Perencanaan, pelaksanaan dan pengendalian teknis kegiatan dan operasi intelijen Kejaksaan berupa penyelidikan, pengamanan dan penggalangan untuk mendukung kebijakan penegakan hukum, baik preventif maupun represif mengenai upaya penyelamatan pemulihan keuangan negara yang meliputi sektor keuangan dan kekayaan negara, pengadaan barang/jasa pemerintah, pelayanan publik dan sektor lainnya, pemberian dukungan terhadap bidang Perdata dan Tata Usaha Negara guna penyelamatan dan pemulihan kekayaan negara, penegakan wibawa pemerintah dan negara serta pemberian pelayanan hukum kepada masyarakat yang meliputi penegakan hukum, bantuan hukum, pertimbangan hukum dan tindakan hukum lain kepada negara atau pemerintah, meliputi lembaga/badan negara, lembaga/instansi pemerintah pusat dan daerah, Badan Usaha Milik Negara/Daerah;

d. Perencanaan, pelaksanaan dan pengendalian teknis kegiatan dan operasi intelijen Kejaksaan berupa penyelidikan, pengamanan dan penggalangan untuk mendukung kebijakan penegakan hukum, baik preventif maupun represif mengenai pemberian dukungan terhadap proses pelaksanaan penanganan perkara, pengawasan pelaksanaan putusan pidana bersyarat, pidana pengawasan, pengawasan pelaksanaan keputusan lepas bersyarat dan tindakan hukum lain dalam tindak pidana umum dan tindak pidana khusus;

e. Pelaksanaan supervisi serta pemberian dukungan terhadap lembaga negara, lembaga pemerintah dan non pemerintah serta lembaga lainnya 
dalam rangka pelaksanaan sistem pengawasan dan pengendalian internal/eksternal dalam upaya pencegahan dan penanggulangan tindak pidana;

f. Mendukung pelaksanaan program pencegahan dan penanggulangan tindak pidana, maupun dalam rangka reformasi sistem peradilan, melalui kerjasama dan koordinasi dengan instansi penegak hukum baik di dalam maupun luar negeri, sosialisasi pencegahan dan penanggulangan tindak pidana kepada pejabat negara, penyelenggara negara, organisasi non pemerintah serta elemen masyarakat lainnya;

g. Perencanaan, pelaksanaan dan pengendalian teknis kegiatan dan operasiintelijen Kejaksaan berupa penyelidikan, pengamanan dan penggalangan untuk mendukung kebijakan penegakan hukum, baik preventif maupun represif mengenai pemberian dukungan berkaitan dengan tindak pidana umum yang diatur di dalam dan di luar KUHP, pemberian dukungan kinerja pelaksanaan tugas bidang pembinaan dan bidang pengawasan;

h. Perencanaan, pelaksanaan dan pengendalian teknis kegiatan dan operasi intelijen Kejaksaan berupa penyelidikan, pengamanan dan penggalangan untuk mendukung kebijakan penegakan hokum baik preventif maupun represif mengenai cegah tangkal, pengawasan media massa, barang cetakan, orang asing, pengawasan aliran kepercayaan masyarakat dan keagamaan meliputi aliran-aliran keagamaan, kepercayaankepercayaan budaya, mistik-mistik keagamaan, mistik-mistik budaya, perdukunan, pengobatan pertabiban secara kebatinan, peramalan paranormal, akupuntur, shin-she, metafisika dan lain-lain yang dapat membahayakan masyarakat dan negara, pencegahan dan penyalahgunaan dan/atau penodaan agama, ideologi, politik, sosial, budaya dan pertahanan dan keamanan, persatuan dan kesatuan bangsa, pelanggaran hak asasi manusia, pencarian dan penangkapan buron Kejaksaan;

i. Perencanaan, pelaksanaan dan pengendalian teknis kegiatan dan operasi intelijen Kejaksaan berupa penyelidikan, pengamanan dan penggalangan untuk mendukung kebijakan penegakan hukum baik preventif maupun represif dalam rangka menyelenggarakan persandian meliputi penyelenggaraan telekomunikasi, pengamanan data dan informasi, kontra penginderaan, pemantauan, penginderaan, pengolahan dan analisa data, pengelolaan operasional Bank Data Intelijen, pembinaan sumberdaya teknologi intelijen, pelaksanaan administrasiintelijen serta penyediaan produksi intelijen;

j. Perencanaan, pelaksanaan dan pengendalian teknis kegiatan penerangan dan penyuluhan hukum, peningkatan kesadaran hukum masyarakat, hubungan media massa, hubungan kerjasama antar lembaga negara, lembaga pemerintah dan non pemerintah, pengelolaan Pos Pelayanan Hukum dan Penerimaan Pengaduan Masyarakat, pengelolaan informasi dan dokumentasi untuk mewujudkan pelayanan yang cepat, tepat dan sederhana sesuai petunjuk teknis standar layanan informasi publik secara nasional dalam rangka mendukung keberhasilan tugas, wewenang dan fungsi serta pelaksanaan kegiatan Kejaksaan;

k. Pengamanan teknis di lingkungan unit kerja Seksi Intelijen dan pemberian dukungan pengamanan teknis dan non teknis terhadap pelaksanaan tugas pada unit kerjalainnya di lingkungan Kejaksaan Negeri, meliputi sumber daya manusia, material/aset, data dan 
informasi/dokumen melalui kegiatan/operasi intelijen dengan memperhatikan prinsip koordinasi;

1. Pembinaan dan pelaksanaan kerjasama dengan kementerian, lembaga pemerintahan non kementerian, lembaga negara, instansi dan organisasi lain terutama pengkoordinasian dengan aparat intelijen lainnya di tingkat Kabupaten/kota; Pemberian saran pertimbangan kepada Kepala Kejaksaan Negeri dan pelaksanaan tugas-tugas lain sesuai dengan petunjuk Kepala Kejaksaan Negeri.

Berdasarkan dari tugas dan

kewenangan Kejaksaan tersebut di atas, maka dapat dikatakan bahwa tugas dan kewenangan Kejaksaan tidak hanya sebatas melakukan pengawalan dan pengamanan jalannya pemerintahan dan pembangunan melalui upaya-upaya preventif dan melakukan penerangan serta penyuluhan hukum dalam setiap tahapan program pembangunan dari awal sampai akhir.

Menindak lanjuti Instruksi Jaksa Agung Nomor 7 tahun 2019 Tentang Pelaksanaan Keputsan Jaksa Agung Nomor 345 Tahun 2019, dalam Petunjuk Pelaksanaan Instruksi Jaksa Agung RI no. 7 tahun 2019 bahwa ;
1. Terhadap kegiatan pengawalan dan pengamanan Tp4D, agar dilakukan Langkah berikut;

1.1.Tidak lagi menerima permohonan pengawalan dan pengamanan kepada TP4D provinsi/Kabupaten/Kota Sejak tanggal 22 November 2019.

1.2. Menginventarisasi dan melakukan pemetaan potensi pemasalahan dalam pelaksanaan kegiatan pengawalan dan pengamanan pemerintahan dalam pembangunan oleh TP4D provinsi/Kabupaten/Kota terhitung sejak tahun 2016 s.d tahun 2018 di wilayah hukumnya masing-masing. Apabila ditemukan permasalahan, maka tindak lanjut penyelesainnya dilakukan melalui koordinasi dengan Aparat Pengawas Itern Pemerintah (APIP) maupun bidang Intelejen, Datun dan/atau Tindak Pidana Khusus

1.3. Melaporkan hasil pelaksanaan kegiataan sebagaimana butir 1.2 di atas, pada kesempatan pertama secara berjenjang kepada Jaksa Agug Muda Intelejen cc Direktur Pengamanan Pembangunan Strategis, paling lambat 31 Januari 2020.

1.4. Senantiasas melakukan pengawasan melekat dalam rangka deteksi dini terhadap bentuk penyalahgunaan kewenangan oleh oknum Kejaksaan Republik Indonesia dalam pelaksanaan tugas penegakan hukum dan pembangunan di wilayah hukumnya yang dapat menciderai kepercayaan public terhadap institusi Kejaksaan Republik Indonesia.

2. Terhadap kegiatan pengamaan pembangunan strategis yangs edang berjalan, agar ditempuh dengan Langkah-langkah berikut; 
2.1. dengan diterbitkannya Keputusan Jakasa Agung No 345 Tahun 2019, maka seluruh kegiatan pengawalan dan pengamanan oleh TP4 dinyatakan berhenti penghentian kegiatan pengawalan dan pengamaan tersebut diberitahukan kepada pemohon melalui surat penghentian pengawalan dan pengamanan proyek strategis

2.2.Menyusun kertas kerja kegitan pengawalan dan pengamanan dengan mengacu pada format sebagaimana surat cq JAM Intelejent No. R1308/D.Dpp/08/2019 tanggal intelejent 26 Agustus 2019 dan melaporkan secara berjenjang kepada JAM intelejent cq Direktur Pengamanan Pembangunan Strategis.

2.3. Apabila dalam kegiatan pemgamanan pembangunan strategis yang berjalan tersebut ditemukan permasalahan hukum maka penyelesaiannya diserahkan kepada bidang Datun atau Tindak Pidana Khusus sesuai dengan ruang Lingkup tugas dan fungsi masingmasing bidang dimaksud, setelah dilakukan koordinansi dengan Aparat pengawas Intern Pemerintah (APIP).

3. Pelaksanaan kegiatan pengamanan pembangunan strategis.

3.1 Pengamanan pembangunan strategis dilaksanakan dengan cara 1) pengkajian undang-undang, 2) pemetaan dan Analisa masalah yang terkait dengan pemerintah dan proyek yang bersifat strategis, 3) pengkajian dan koordinasi dengan pengawas intern pemerintah dalam hal penilaian kebijakan yang dilakukan oleh pelaksana kegiatan dan 4) penyusunan perkiraan keadaan intelejen terhadap 20 sektor pembanguan strategis sebagaimana diatur dalam pasal 223 Peraturan Jaksa Agung No. PER-
006/A/JA/2017 tentang Organisasi dan Tata Kerja Kejaksaan RI.

3.2 Pengadministrasisan dan pelaporan pelaksanaan kegiatan pengamanan pembangunan strategis dilakukan berdasarkan Peraturan Kejaksaan No, 4 tahun 2019 tentang Administrasi Intelejent Kejaksaan RI dan Kepja No KEP135/A/JA/05/2019 tentang Format Bentuk Kode dan Cara Pengisian Administrasi Intelejen Kejaksaan;

3.3 Memperhatikan ketersidiaan anggran saat ini maka pelaksanaan pengamann pembangunan strategis dan satuan kerja Kejaksaan Tinggi dan Kejaksaan Negeri dilakukan dengan menyesuaikan ketersediaan anggaran kegiatan LID/PAM/GAL intelejen pada satuan kerja masingmasing. Untuk itu agar pada pimpinan unit kerja lebih selektif dalam melakukan kegiatan pengamanan pembangunan strategis sesuai dengan prioritas pembanganuan dalam wilyah hukumnya.

Batasan tentang pengawasan sangat

bervariatif, tetapi intinya adalah untuk mengontrol, mengendalikan dan memperbaiki bekerjanya manajemen pemerintahan agar mencapai tujuan yang diharapkan sesuai rencana, norma dan standarisasi yang telah ditetapkan

\section{KESIMPULAN}

Kedudukan Kejakasan dalam sistem pengawasan adalah sebagai fungsi pengawasan proyek strategis nasional. 
Namun dalam menjalankan fungsi

pengawasan dalam pencegahan tindak

pidana korupsi pada proyek strategis

nasional tetap berkoordinasi dengan

lembaga pengawasan negara lainnya dan

berdasarkan peraturan perudangan-

undangan dan secara teknis telah diatur

dalam Instruksi Jaksa Agung Nomor 7

tahun 2019 Tentang Pelaksanaan Keputsan

Jaksa Agung Nomor 345 Tahun 2019,

dalam Petunjuk Pelaksanaan Instruksi

Jaksa Agung RI no. 7 tahun 2019.

\section{DAFTAR PUSTAKA}

Achmad Ali, 2009, Menguak Teori Hukum (Legal Theory) dan Teori Peradilan (Judicialprudence) Termasuk Interpretasi UndangUndang (Legisprudence), Kencana, Jakarta

Adam Chazawi, 2010, Pelajaran Hukum Pidana 1, Rajagrafindo Persada, Jakarta, Cetakan ke-5

Andi Hamzah, 2008, Pemberantasan Korupsi melalui hukum pidana nasional dan internasional, Rajawali Pers, Jakarta

Chaerul Amir, 2014, Kejaksaan Memberantas Korupsi (Suatu Analisis : Historis, Sosiologis, dan Yuridis), PRO dealeader, Jakarta

Chairul Huda, 2013 Dari „Tiada Pidana Tanpa Kesalahan" menjadi kepada „Tiada Pertanggungjawaban Pidana Tanpa Kesalahan", Kencana, Jakarta

Erdianto Efendi, 2011, Hukum Pidana Indonesia - Suatu Pengantar, Refika Aditama, Bandung

Laden Marpaung, 2001 Tindak Pidana Korupsi, Pemberantasan dan Pencegahan, Djambatan, Jakarta

Oos. M. Anwas, 2013, Pemberdayaan Masyarakat di Era Global, Alfabeta, Bandung

Surachmin (et.al), 2011, Strategi \& Teknik Korupsi : Mengetahui Untuk Mencegah, Sinar Grafika, Jakarta

Teguh Prasetyo, 2012, Hukum PIdana, Raja Grafindo, Jakarta.

Yudi Kristina, 2006, Independesi Kejaksaan Dalam Penyidikan Korupsi, Citra Aditya Bakti, Bandung

Yogi Prasetyo, Makalah : "Pendidikan Anti Korupsi sebagai Upaya Preventif Pencegahan Korupsi”, Universitas Muhammadiyah Ponorogo, Ponorogo, Jawa Timur, 29 Juni, 2013

Transparancy International, dapat diakses di

http://www.transparency.org/c pi2014/results,

Kejaksaan Agung Republik Indoneisa,Dapat di akses di : //www.kejaksaan.go.id/unit_ke jaksaan.php?idu $=22 \& s m=2$

Kejaksaan Republik Indonesia, dapat diakses di https://www.kejaksaan.go.id/k 
egiatan.php?idu $=29 \& \mathrm{sm}=4 \& \mathrm{id}$ $=150 \&$ hal $=2$

Kejaksaan Agung Republik Indonesia, dapat diakses di : https://www.kejaksaan.go.id/k egiatan.php?idu=29\&sm=4\&id $=150 \&$ hal $=2$ 
